\title{
Liveweight Changes and Reproductive Performance of Snails (Archachatina Marginata) Under Controlled and Naturally Induced Aestivation
}

\author{
*Omoyakhi ${ }^{1}$, J.M., Edo-Taiwo ${ }^{2}$, O., Aremu ${ }^{3}$, O.T., Okhale ${ }^{1}$, O.E. \\ ${ }^{1}$ Department of Animal Science, Faculty of Agriculture, University of Benin, Benin City, Nigeria \\ ${ }^{2}$ Department of Animal and Environmental Biology, Faculty of Life Science, University of Benin, Benin City, \\ Nigeria \\ ${ }^{3}$ Department of forestry and wildlife, Faculty of Agriculture, University of Benin, Benin City, Nigeria
}

\begin{abstract}
The liveweight changes and reproductive performance of snails (Archachatina marginata) under controlled (watered throughout the experimental period, aestivated for 6 and 12 weeks) and naturally induced aestivation were investigated. Eighty (80) reproductively matured snails with five snails replicated four times in a completely randomized design were used. Liveweight and mortality were monitored during aestivation. Eggs collected were incubated. While the continuous watered group $(0 \mathrm{~A})$ gained $11.95 \mathrm{~g}$, the groups aestivated for 6 weeks (6A), 12 weeks $(12 \mathrm{~A})$ and by nature $(N)$ respectively recorded $-40.05,-88.28$ and $-51.29 \mathrm{~g}$. Mortality records showed 1, 1, 2 and 0 . Apart from clutch size and number of snailet hatched, the investigated reproductive indices reflected significant $(P<0.05)$ differences. The average clutch number was highest in $0 A$ (5.65) followed by $12 \mathrm{~A}$ (4.25), 6A (2.80) and $N$ (2.67). Clutch weight was highest in $N(25.17 \mathrm{~g})$ which differ statistically from $O A$ (21.54). This was however not significantly different from $6 \mathrm{~A}(22.88 \mathrm{~g})$ and $12 \mathrm{~A}(24.32 \mathrm{~g})$. These respectively gave an average egg weight of 2.92, 2.91, 3.16 and $3.21 \mathrm{~g}$ for $0 \mathrm{~A}, 6 \mathrm{~A}, 12 \mathrm{~A}$ and $\mathrm{N}$. Hatchability was significantly highest in 6A (95.92\%) which was not significantly different from $12 \mathrm{~A}(93.69 \%)$ and $N(89.48 \%)$. The later however, did not differ statistically from OA. OA nevertheless gave the highest snailet weight $(2.63 \mathrm{~g})$ and the least was recorded from $6 \mathrm{~A}(1.53 \mathrm{~g})$. It is evident from this study that aestivation although depressed weight and overall number of eggs laid, it however favoured hatchability and incubation period in A. marginata.
\end{abstract}

Keywords: Aestivation, Archachatina marginata, liveweight, Reproductive performance, egg

\section{Introduction}

In Nigeria, snails are collected from the wild and there has been noticeable decline in wild stock. Of serious concern is that in recent time, the popular Achatina achatina has been observed in much short supply in Nigeria. Beside this decline in this and several other species, it is also noted that meeting the current and anticipated demand for snail meat and products cannot rely on wild supply (Omoyakhi and Okhale, 2015a). Clearly, availability of captive bred snails among other things will augment the exploitation of the wild stock. Snails have been included to a group called miniframe species of livestock that are increasingly playing important role in human nutrition (Eruvbetine, 2012). Snails are tractable, prolific and widely accepted for public healthy consumption and have been described as one of the surest ways of ameliorating the shortfall of animal protein in Nigeria (FAO, 1970; Mbah, 1989 and Onadeko, 2002). In view of this, the rearing of snail in captivity is attracting the keen interest of both scientists and farmers, suggesting the potential of this species as farm animal of the future in the West Africa sub-region.

In captive rearing and management of wild species of animals like snail, Okhale et al. (2015) asserted that utmost attention should be given to their life pattern as provided by nature in order to maximize their survival, growth and reproductive potential. Consequently, practices capable of adverse short or long term effects are avoided. This also enables conditions and factors vital for sustainable and optimal productivity to be integrated in captive rearing and management of wild species of animals. This study therefore seeks to investigate the liveweight changes and reproductive performance of snails (Archachatina marginata) under controlled (watered throughout the experimental period, aestivated for 6 and 12 weeks) and naturally induced aestivation.

\section{Experimental Location}

\section{Materials And Methods}

The research was carried out at the Snailry unit of the University Teaching and Research Farm, University of Benin, Edo State, Nigeria. The farm is located within the tropical rain forest vegetation zone of Southern Nigeria, lying between longitude $5^{\circ} \mathrm{E}$ and $6^{\circ} 42^{\prime} \mathrm{E}$ and latitude $5^{\circ} 45$ and $7^{\circ} 34^{\prime} \mathrm{N}$ of the equator (NAA, 
2015). On the north Edo State is bounded by Kogi State, to the east is Anambra State, south by Delta State and west by Ondo State. The climate of Edo is humid.

\section{Materials}

The materials used include a total of 80 healthy snails of Archachatina marginata with liveweight of 150 to 280 $\mathrm{g}$, shallow containers for feed and water, a sensitive electronic weighing scale, identification materials and plastic incubators.

\section{Experimental design}

The experiment was laid out in a completely randomized design (CRD). Eighty (80) reproductively matured snails with five snails replicated four times were used. Liveweight and mortality were monitored during aestivation and the reproductive performance post aestivation.

\section{Experimental procedure}

The brick hutches $(90 \mathrm{~cm}$ square with a depth of $54 \mathrm{~cm}$ ) were prepared and assigned shallow plastic troughs $(10 \mathrm{~cm} \times 6 \mathrm{~cm} \times 2 \mathrm{~cm})$ for concentrate feed. The snails were balanced for liveweight and randomly allotted to the four treatments. Feeding and watering were provided as necessitated for the study. The feed materials supplied included fruits of pawpaw and water melon, leaves of cocoyam, pumpkin, plantain and water leaves. The concentrate was formulated with the following nutritional information (calculated); $\mathrm{CP}=16 \%$, ME $=2,469.40 \mathrm{kcal} / \mathrm{kg}, \mathrm{CF}=5.79 \%, \mathrm{EE}=3.91 \%, \mathrm{Ash}=3.67 \%, \mathrm{NFE}=49.05 \%$, Lysine $=0.59 \%$, Met + cyst $=$ $0.50 \%, \mathrm{Ca}=5.31$ and $\mathrm{P}=1.07$.

Routinely, cleaning of troughs, regular clean-up and changing of the feeds as well as regular check for insects and other predators were ensured. The trench around the cells was also provided with water and suitable pesticides to prevent insect and other pests from crawling into the cells.

Snails in group $0 \mathrm{~A}$ were fed, watered and moistened throughout the experimental period. Group 6A and $12 \mathrm{~A}$ were allowed a 6 - and 12 - week unbroken aestivation period while snails in group $\mathrm{N}$ were controlled by natural weather elements. Group 6A was induced 6 weeks after Group 12A had been induced. This enabled termination of aestivation of all the groups and simultaneous data collection.

Two (2) weeks acclimatization (adjustment) period was allowed prior to the commencement of the research which was programmed for the month of December. This enabled the completion of all the aestivation lengths (including the 12 weeks aestivation length) within the pre-spawning period of GALS in the tropics which last from March to April as reported by Cobbinah (1992). Egg production in each group was monitored up to month of August. Eggs laid were collected and incubated immediately.

\section{Statistical analysis}

The data obtained for reproductive performance were subjected to one way analysis of variance (ANOVA) using Genstat, 2009 ( $12^{\text {th }}$ Edition) and significant treatment means were separated by Duncan Multiple Range Test.

\section{Experimental design and induction of aestivation}

The experiment was conducted using 80 reproductively matured snails, laid out in a completely randomized design, with 5 snails replicated four times. Snails were induced to aestivate under prevailing atmospheric conditions in this study by discontinued moistening of soils and withdrawal of feed and water as reported in several researches on snail aestivation (Omoyakhi et al., 2008a, b, Ajayi et al., 2012; Adeoba et al., 2012).

\section{Result \\ Weight change and mortality of Archachatina marginata Under Natural and Varying Aestivation Lengths}

Analysis of variance as shown in table 4.1 reflects significant $(\mathrm{P}<0.05)$ weight loss of the aestivated $(6$ and 12 weeks) and naturally induced group. These were not significantly different from each other but differ significantly from the group that was watered throughout the experimental period. The continuous watered group however, only gained $11.95 \mathrm{~g}(6.01 \%)$ throughout the investigation periods. The weight loss was highest in the 12th week aestivated group $(-88.28 \mathrm{~g})$ followed by the naturally controlled group $(-51.29 \mathrm{~g})$ and then the 6 weeks aestivation treatment group (-40.05 g). This accounted for about $35.41 \%, 23.82 \%$ and $16.41 \%$ of their respective initial weight. The 12 weeks aestivation treatment group suffered 2 mortalities (in week 2 and 12) and one (1) each from the 6 weeks induced aestivation group and the continuous watering groups. No mortality was recorded in the naturally controlled group. The trend in the change in weight in the respective treatment groups is shown in figure 1 . The continuous watered group experienced stable weight changes. Noticeable loss in weight was observed in week two and gain in the 12th week. The aestivated groups (including the naturally 
controlled) had consistent drop in weight. Major weight loss was observed in week 2 and 8 in the 12 weeks aestivation group. The naturally induced aestivation group had a slight gain in weight, thereafter a fairly stable weight up to the 7th week. Only marginal weight loss was observed in the 2 nd week of aestivation in the 6 weeks aestivation treatment group.

Table 1: Mean Weight Change and Mortality of Archachatina marginata Under Natural and Varying Aestivation Lengths

\begin{tabular}{|l|l|l|l|l|l|}
\hline & Continuous watered & 6 weeks & $\mathbf{1 2}$ weeks & Naturally controlled & SEM \\
\hline Initial Weight $(\mathrm{g})$ & $199.00^{\mathrm{b}}$ & $244.10^{\mathrm{a}}$ & $249.30^{\mathrm{a}}$ & $215.30^{\mathrm{ab}}$ & 13.97 \\
\hline Final Weight $(\mathrm{g})$ & $206.80^{\mathrm{a}}$ & $182.8^{\mathrm{ab}}$ & $161.00^{\mathrm{b}}$ & $164.00^{\mathrm{b}}$ & 9.71 \\
\hline Weight change $(\mathrm{g})$ & $11.95^{\mathrm{a}}$ & $-40.05^{\mathrm{b}}$ & $-88.28^{\mathrm{b}}$ & $-51.29^{\mathrm{b}}$ & 16.40 \\
\hline Mortality & 1 & 1 & - & \\
\hline
\end{tabular}

Values are least square means ( \pm sem)

${ }^{\mathrm{abc}}$ Means with different superscripts within the same parametric row differ significantly $(\mathrm{P}<0.05)$

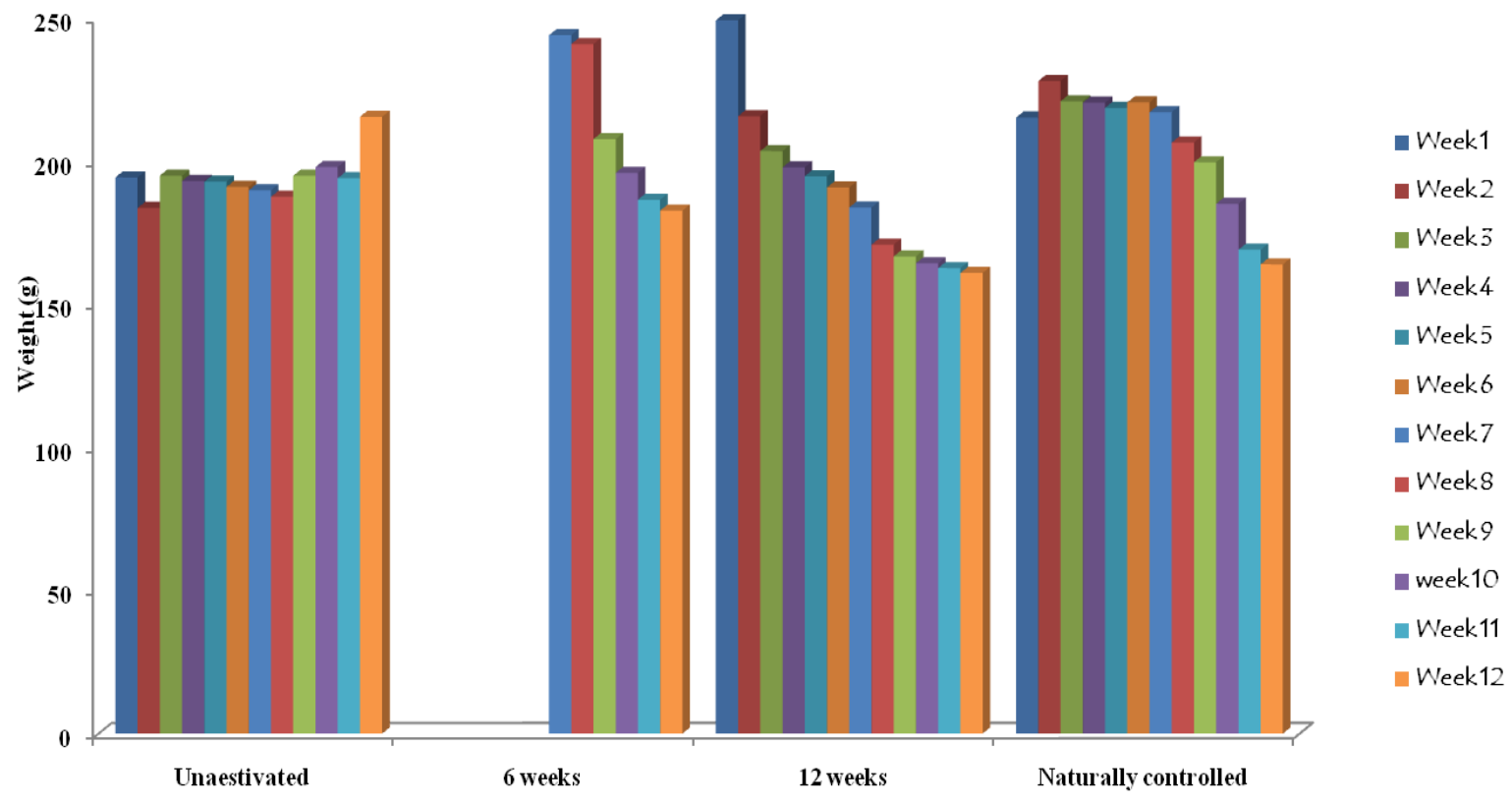

Aestivation treatments

Figure 1: Trend in Weight Change over the weeks of Aestivation of Archachatina marginata Under Natural and Varying Aestivation Lengths

Reproductive performance of Archachatina marginata Under Natural and Varying Aestivation Lengths

Apart from clutch size and number of snailet hatched, the investigated reproductive performance indices as shown in table 4.3 reflected significant $(\mathrm{P}<0.05)$ differences among the treatments. The averages clutch number was significantly highest in the continuous watering group (5.65) and followed by the 12 weeks aestivation group (4.25). The 6 weeks aestivation group recorded 2.80 average numbers of clutches. Clutch weight was highest in the naturally controlled group $(25.17 \mathrm{~g})$, which was different statistically from the continuous watering group (21.54). It was however not significantly different from the $6(22.88 \mathrm{~g})$ and the 12 weeks (24.32 g) groups. These respectively gave an average egg weight of $2.92 \mathrm{~g}, 2.907 \mathrm{~g}, 3.16 \mathrm{~g}$ and $3,21 \mathrm{~g}$ for the continuous watering group, 6,12 and naturally controlled aestivation groups. Hatchability was significantly highest with the 6 weeks aestivation group $(95.92 \%)$ which was not significantly different from the 12 weeks $(93.69 \%)$ and naturally controlled group $(89.48 \%)$. The later however did not differ statistically from the continuous watering group $(85.83 \%)$. This nevertheless gave the highest snailet weight $(2.63 \mathrm{~g})$ and the least recorded from the 6 weeks aestivation group. 
Table 2: Reproductive performance of Archachatina marginata Under Natural and Varying Aestivation Lengths

\begin{tabular}{|l|l|l|l|l|l|}
\hline \multirow{2}{*}{ Reproductive Indices } & \multicolumn{2}{l|}{ Aestivation treatments } & $\mathbf{\pm S E M}$ \\
\cline { 2 - 5 } & Continuous watering & $\mathbf{6}$ weeks & $\mathbf{1 2}$ weeks & Naturally controlled & \\
\hline Date of first egg lay & $56.00^{\mathrm{c}}$ & $92.00^{\mathrm{a}}$ & $98.00^{\mathrm{a}}$ & $64.00^{\mathrm{b}}$ & 2.020 \\
\hline Clutch number & $5.653^{\mathrm{a}}$ & $2.800^{\mathrm{c}}$ & $4.250^{\mathrm{c}}$ & $2.667^{\mathrm{c}}$ & 0.290 \\
\hline Clutch size & $7.437^{\mathrm{a}}$ & $7.490^{\mathrm{a}}$ & $7.983^{\mathrm{a}}$ & $7.540^{\mathrm{a}}$ & 0.303 \\
\hline Clutch weight (g) & $21.54^{\mathrm{b}}$ & $22.88^{\mathrm{ab}}$ & $24.32^{\mathrm{ab}}$ & $25.17^{\mathrm{a}}$ & 0.982 \\
\hline Average egg weight (g) & $2.917^{\mathrm{a}}$ & $2.907^{\mathrm{a}}$ & $3.157^{\mathrm{a}}$ & $3.210^{\mathrm{a}}$ & 0.209 \\
\hline Incubation period (days) & $29.33^{\mathrm{a}}$ & $25.33^{\mathrm{b}}$ & $25.33^{\mathrm{b}}$ & $26.00^{\mathrm{b}}$ & 0.408 \\
\hline Number hatched & $5.933^{\mathrm{a}}$ & $5.917^{\mathrm{a}}$ & $6.257^{\mathrm{a}}$ & $4.667^{\mathrm{a}}$ & 0.583 \\
\hline Hatchability (\%) & $85.83^{\mathrm{b}}$ & $95.92^{\mathrm{a}}$ & $93.69^{\mathrm{a}}$ & $89.48^{\mathrm{ab}}$ & 2.520 \\
\hline Weight of hatchling & $16.06^{\mathrm{a}}$ & $10.48^{\mathrm{b}}$ & $16.52^{\mathrm{a}}$ & $15.18^{\mathrm{a}}$ & 0.711 \\
\hline Weight of snailet & $2.630^{\mathrm{a}}$ & $1.530^{\mathrm{c}}$ & $2.227^{\mathrm{ab}}$ & $1.833^{\mathrm{bc}}$ \\
\hline
\end{tabular}

Values are least square means $( \pm$ sem)

${ }^{\mathrm{abc}}$ Means with different superscripts within the same parametric row differ significantly $(\mathrm{P}<0.05)$

\section{Discussion}

There was significant decline in liveweight of snails in all the aestivated groups. The percentage decline correlates relatively to the aestivation lengths. This may be partly due to autophagy and/or the use of a large amount of energy reserves in different body tissue (Lukong and Onwubiko, 2004; Omoyakhi and Okhale, $2015 \mathrm{~b}, \mathrm{c})$. In this study, while the continuous watered group gained $6.01 \%$ of its initial weight, 35.41, 16.41 and $23.82 \%$ weight loss were observed from 6A, 12A and $\mathrm{N}$ respectively. In a similar research, Emerson and Duer (1967) reported weight reduction of $62 \%$ in Littorina planoxis. About $50 \%$ loss in weight was also reported by Russel-Hunter and Eversole (1976) after 132 days of starvation in the fresh water pulmonate snail, Helisona trivolvis. Lukong and Onwubiko (2004) observed a liveweight decline of $44.60 \%$ in Achatina achatina aestivated for 4 months. Omoyakhi (2008a) and Abdusamad et al. (2010) reported a liveweight reduction of $52.4 \%$ and $35.6 \%$ of initial weight for A. marginata after six weeks of aestivation respectively. Snails undergo aggressive recovery when the environment becomes favourable and water and feed are available post aestivation (Cobbinah, 1992, Rizzatti and Romero, 2001). Omoyakhi and Osinowo (2010a,b) observed significant compensation for this loss in liveweight and other components studied after snails were arouse of aestivation. They noted that, within two weeks post-aestivation, the liveweight exceeded their pre-aestivation values by $192.6 \%$ for Archachatina marginata. The first egg lay recorded was from the continuous watered group (25th February). This coincided with the date of the third rain of the year in the study area. The first two rains would probably have triggered the initiation of the reproductive behaviour and consequently the commencement of egg lay. The $\mathrm{N}$ group had its first lay on the 5th March. Bonnefoy-Claudet and Deray (1984) reported 52 and 85 days as day of first mating and egg lay respectively for Cantareus aspersus hibernated for 1.5 months. Omoyakhi and Osinowo (2012) reported 72 days for first record of egg lay in A. marginata and 86 days for $A$. achatina aestivated for 6 weeks. The delay may be due to necessary period required for reproductive tissue recovery and mobilization of necessary nutrient for egg formation. Omoyakhi and Okhale $(2015 b, c)$ observed diminished tissue content of the reproductive organs of snails that were aestivated for 6 weeks. They reported progressive recovery with re-appearance of the lumen and follicular enlargement within 3 and 6 weeks post aestivation when the histology of the reproductive organs was studied (Omoyakhi and Okhale, 2015d,e).

Depression in the number of clutches was observed in the aestivated groups. Omoyakhi and Osinowo (2012) reported similar trend with 6,4, 4 and 3 clutches for 0,2, 4 and 6 weeks aestivation lengths respectively. But $12 \mathrm{~A}$ in this study however, recorded better result (4.25) than the 6A (2.88) by $51.79 \%$ and by $59.36 \%$ of the naturally controlled group (2.67). Bonnefoy-Claudet and Deray (1984) reported enhanced mating interval by hibernating Cantareus aspersus. The incubation period ranged from 25.33 days (in the 6A and 12A) to 29.33 days (recorded from the continuous watering group). The continuouswatered group (29.33) compared favourably with the records of Odaibo (1997), Akinnusi (1998), Akegbejo-Samson and Akinnusi (2000) and Awah et al. (2001) who reported between 28 and 32.68 days for A. marginata. The restricted groups had significantly lower incubation period which may be connected with the source and management. The 0A has a history of continuous watering over time but the other groups were collected from the wild and were naturally controlled. Omoyakhi (2007) similarly recorded slightly lower incubation period in the aestivated group as compared with the watered group. This may therefore be adduced to the phenomenon of aestivation but the physiological reason for this observation was not identified in this study. Clutch size was not significantly affected by aestivation. Percentage hatchability was however improved. The values obtained generally in this study was higher than the ranges of 42.86 to $65.71 \%$ (Omoyakhi and Osinowo, 2012), and 35 to $71.9 \%$ (Adeniran, 2000) earlier reported. It was comparable with the ranges of 73.4 to $98 \%$ (Akegbejo-Samson and Akinnusi, 2001) and 84 to $100 \%$ recorded by Akinnusi (2000). It is evident from this study that aestivation although depressed weight and overall number of eggs laid, it however favoured hatchability and incubation period in A. marginata. 


\section{References}

[1] Abdussamad, M. A., Osinowo, O. A., Smith, O. F. and Onadeko, S. A. (2010). Some haemolymph biophysical parameters in Giant African Land Snails (Archachatina marginata) during six weeks aestivation period: Global Veterinaria 4 (4): $400-408$.

[2] Adeniran, E.O. (2000). Reproductive performance of the giant African land snails Archachatina marginata at different body weights B. Agric Project FUNAAB p. 15 Unpublished.

[3] Adeoba, M. I., Osinowo, O. A., Oyewale, J. O. and Onagbesan O. M. (2012). Effects of aestivation on heart rate of Archachatina marginata, Swainson 1981 at two liveweight groups. Proceedings of the $1^{\text {st }}$ Intl Confr. on Giant African Land Snails. Feb. 2012. Abeokuta, Nig. Pp $105-108$

[4] Ajayi, O.A., Fawole, J.K. Idowu, A.B. and Ademolu, K.O. (2012). Dynamics of nutrients in the tissues of Giant African Land Snail (Archachatina marginata) during aestivation. Proceedings of the $1^{\text {st }}$ Intl Confr. on Giant African Land Snails. Feb. 2012. Abeokuta, Nig. Pp $67-70$

[5] Akegbejo-Samson, Y. and Akinnusi, O. (2001). Effect of population density on the growth rate and egg laying capacity of giant African land snail, A. marginata (Swainson). Nigeria Journal of Animal Production 27 (1): 90-103.

[6] Akinnusi, O (1998). Life History studies of Archachatina marginata (Swainson). A paper presented at Silver Anniversary of NSAP, March 21-26, Abeokuta. 402-404p

[7] Akinnusi, O. (2002). Introduction to Snail and Snail Farming. Triola Exquisite Venture, Abeokuta, Nig. P 70

[8] Akinnusi, O. (2000). "Snail Rearing-case study of Abeokuta, Ogun State, Nigeria. Proceedings of 5" Annual confr. ASAN Port Harcourt, Nigeria. Sept. $19-22,2000$

[9] Awah, A.A., Edeogbon, C.O., Lalabe, B.C. and Omo-Erigbe P. (2001). Snail farming in matured rubber plantation: 4 shidi on some artificial methods for hatching of snail eggs and protection of young snails during the dry season. Tropicultura. 19 (4): $194-196$.

[10] Bonnefoy-Claudet, R. and Deray, A. (1984). Influence de la durée d'hibernation sur l'activité reproductrice de l'escargot Helix aspersa Müller. Comptes Rendus de la Société de Biologie 178, 442-449

[11] Cobbinah, J.R. (1992). Snail farming in West Africa. A practical guide, CTA, UK, p 1 - 15.

[12] Emerson, D.N. and Duer, F. (1967). Some Physiological effects of starvation in interstidal prosobranch (Littorina planaxis) (Philippi, 1847); Comp. Bioch. Physiol. 20 40-50

[13] Eruvbetine, D. (2012). Nutrition and feeding strategies of the Giant African Land Snail. Proceedings of the $1^{\text {st }}$ Intl Confr. on Giant African Land Snails. Feb. 2012. Abeokuta, Nig. P. 8

[14] FAO. (2002). Alternative Protein Sources, Snail and Cane Rats. Food and Agricultural Organisation, Rome, Italy.

[15] FAO, (1970). Food and Agricultural Organisation, Rome, Italy. Management of snails in the tropics. FAO Tech.Paper 45pp

[16] Genstat (2009). Genstat PC/Windows Vista package, version 12.1. Laws Agricultural Trust, Rothamsted experimental station.

[17] Lukong, C.B. and Onwubiko, H.A. (2004). Calcium, copper, protein and oxygen affinity in haemocyanins of aestivating and nonaestivating snails (Achatina achatina) Bio-Research, 2: 115-125

[18] Mbah, L.A.K. (1989). The influence of age and season of stand on the nutritive value of elephant grass (Pennisetum purpurium) and sugar cane (Saccharium officinarium) fed to Canerat (Thryonomis swinderianus). M.Sc. dissertation, University of Ibadan, Nigeria

[19] Odaibo, A.B. (1997). Snail and Snail Farming, Nigerian Edible Land Snails. Stirling-Horden Publisher, Ibadan. Pp 20 - 24

[20] Okhale, O.E. and Omoyakhi, J.M. and Akinwale, W.E. (2015). Dynamics of Some Primary Reproductive Hormones through Aestivation and Arousal of Giant African Land Snails (Archachatina marginata). Journal of Forestry, Environment and Sustainable Development. 1(1) 114-118.

[21] Omoyakhi, J.M. and Okhale, O.E. (2015a). Haemocytological dynamics of giant African land snails (Archachatina marginata) under aestivation and arousal. $3^{\text {rd }}$ ASAN-NIAS JAM Confr.6-10th Sept., 2015 196-202

[22] Omoyakhi, J.M. and Okhale, O.E. (2015b). Histological Changes of the Male and Hermaphroditic Reproductive Organs of Giant African Land Snails (Archachatina marginata) in Aestivation Lengths. Nig. J. Agr. Food and Env. 11(1) 84-89

[23] Omoyakhi, J.M. and Okhale, O.E. (2015c). Histological and Histochemical Changes of the Female Reproductive Organs of Giant African Land Snails (Archachatina marginata) with lengths of Aestivation Nig. J. Agr. Food and Env. 11(1) 90-94

[24] Omoyakhi, J.M. and Okhale, O.E. (2015d). Post Aestivation Dynamics of the Male and Hermaphroditic Reproductive Organs of Giant African Land Snails (Archachatina marginata): Histological and Histochemical Perspective. Nig. J. Life Sc. 5(1). 188-194

[25] Omoyakhi, J.M. and Okhale, O.E. (2015e). Post Aestivation Dynamics of the Female Reproductive Organs of Giant African Land Snails (Archachatina marginata): Histological and Histochemical Perspective. Nig. J. Life Sc. 5(1). 196-202

[26] Omoyakhi, J. M. and Osinowo, O. A. (2012): Comparative reproductive characteristics of giant African land snails, (Archachatina marginata and Achatina achatina) under different length of aestivation. Proceedings of the $1^{\text {st }}$ Intl Confr. on Giant African Land Snails Pp148-151.

[27] Omoyakhi, J.M., Osinowo, O.A., Onadeko, S.A. and Ozoje, M.O. (2008a). Adaptive changes in growth and morphological composition of aestivating giant African land snails, Archachatina marginata and Achatina achatina. African Journal of General Agriculture. (4) 4: 241-249

[28] Omoyakhi, J.M., Osinowo, O.A., Onadeko S.A. and Ozoje, M.O. (2008b). Chemical adjustments during aestivation by giant African land snails, Archachatina marginata and Achatina achatina. African Journal of General Agriculture. (4) 4: 251-258

[29] Omoyakhi, J.M. and Osinowo, O.A. (2010a). Constitutive and adaptive changes of giant African land snails, Archachatina marginata and Achatina achatina, to support transition from the aestivating state to arousal. Archives of Applied Science Research, 2010, 2 (3): $33-41$

[30] Omoyakhi, and Osinowo, (2010b). Modification of some biochemical activities in response to transition of giant african land snails, (Archachatina marginata and Achatina achatina) from aestivation to an active state. Archives of Applied Science Research, 2010, 2 (3): $53-60$

[31] Omoyakhi, J. M. and Osinowo, O. A. (2011a). Aestivation and arousal interaction in the determination of reproduction in giant African land snails: 1. Preliminary morphometric study of the male organs. Nig. Soc. Experimental Biol. J. 11(4) xx (In press)

[32] Omoyakhi, J. M. and Osinowo, O. A. (2011b). Aestivation and arousal interaction in the determination of reproduction in giant African land snails: 2. Preliminary morphometric study of the female organs. Nig. Soc. Experimental Biol. J. 11(4) xx (In press)

[33] Onadeko, S.A. (2002). Gonadal and extra gonadal sperm reserves of the grasscutter (Thryonomis swinderianus Temminck). ASSET Series A. 2(1): 139-145

[34] Rizzatti, A.C.S. and Romero, S.M.B. (2001). Heart rate and body weight alterations in juvenile specimen of tropical land snail Megalobulimus Sanctipauli during dormancy. Braz. J. Med. Biol. Res. 34 (7). Pp 959 - 967.

[35] Russel-Hunter, W.D. and Eversole, A.G. (1976). Evidence for tissue degrowth in starved freshwater pulmonate snails (Helisoma trivolvis) from tissue, carbon, and nitrogen analyses. Comp Biochem Physiol A Comp Physiol. 54 (4):447-53 